\title{
The cleavage fragment of retinoid $X$ receptor- $\alpha$ ligand binding domain inhibits radiosensitization by retinoic acid
}

\author{
YOUNG-MIN CHO, AE-HEE YANG, BU-YEON KIM and YOUNG-HOON HAN \\ Division of Radiation Cancer Biology, Korea Institute of Radiological and Medical Sciences, Seoul 139-706, Korea
}

Received December 16, 2009; Accepted February 24, 2010

DOI: $10.3892 /$ or_00000816

\begin{abstract}
Retinoid $\mathrm{X}$ receptor- $\alpha(\mathrm{RXR} \alpha)$ fragments are known to be produced in some cancer cells by proteolytic cleavage. Previous finding that ligand binding domain (LBD) fragment of RXR $\alpha$ specifically inhibits retinoic acid receptor- $\gamma$ $(\operatorname{RAR} \gamma)$ activity led us to investigate the functional role of $\mathrm{RXR} \alpha \mathrm{LBD}$ fragment in radiosensitization by retinoic acid (RA). Ectopic expression of RXR $\alpha$ LBD fragment in cells that do not have a detectable endogenous $\mathrm{RXR} \alpha \mathrm{LBD}$ fragment, blocked synergistic radiosensitizing action of RA, as determined by growth inhibition, cell death and colony formation assays. However, H460 cell, which has an endogenous $\mathrm{RXR} \alpha \mathrm{LBD}$ fragment, was not radiosensitized by RA regardless of the ectopic $\mathrm{RXR} \alpha \mathrm{LBD}$ fragment expression. These results were paralleled with the pattern of $\mathrm{p} 21^{\text {Waf } 1 / \text { Cip } 1}$ induction by the treatment of RA in combination with ionizing radiation (IR). Taken together, we hypothesize that the RXR $\alpha$ LBD fragment may act as a negative regulator of radiosensitizing effect of RA by restricting the RAR $\gamma$ mediated biological response to RA.
\end{abstract}

\section{Introduction}

All-trans retinoic acid (RA), the major physiologically active form of vitamin A metabolites, exerts profound effects on many biological processes, including cell proliferation, differentiation and morphogenesis (1). The pleiotropic effects of RA are mediated by the retinoic acid receptors (RARs) and their heterodimerization partners, the retinoid $\mathrm{X}$ receptors (RXRs) $(2,3)$. RARs consist of 3 subtypes, $\alpha, \beta$ and $\gamma$. Some extent of functional redundancy among three subtypes of RARs in retinoid signaling has been demonstrated in various context (3-5). However, many lines of evidence indicate that each subtype of RARs plays a distinct role in a variety of biological processes (6). RAR $\gamma$ was reported to be the main mediator for the RA-induced growth inhibition and apoptosis in keratinocytes $(7,8)$, and for the regulation of the

Correspondence to: Dr Young-Hoon Han, Division of Radiation Cancer Biology, Korea Institute of Radiological and Medical Sciences, Gongneung-dong 215-4, Nowon-gu, Seoul 139-706, Korea E-mail:yhhan@kcch.re.kr

Key words: radiosensitization, retinoic acid, $\mathrm{RAR} \gamma, \mathrm{RXR} \alpha$ balance between hematopoietic stem cell self-renewal and differentiation (9).

In a recent study, we have demonstrated that RAR $\gamma$ is distinguished from other RAR subtypes by its unique cytoplasmic localization, which is regulated by complex interactions among ligand binding, phosphorylation, and receptor dimerization (10). We also explored a novel function of the ligand binding domain (LBD) fragment of $\mathrm{RXR} \alpha$ as a specific negative regulator of $\operatorname{RAR} \gamma$. The $\mathrm{RXR} \alpha \mathrm{LBD}$ fragment inhibits nuclear translocation, receptor dimerization and consequently the transcriptional activity of RAR $\gamma$ in a very specific manner without affecting those of RAR $\alpha$ and $-\beta$ subtypes. In relation to this observation, it is worth noting that $\mathrm{RXR} \alpha$ can actually be cleaved in vivo to produce a fragment of similar size to LBD fragment of RXR $\alpha$. Two research groups have previously reported that they detected proteolytic activity to cleave $\operatorname{RXR} \alpha$ at near $\mathrm{N}$-terminus yielding $\mathrm{C}$-terminal fragments of several sizes and characterized the responsible proteases as cathepsin L-type protease and m-calpain, respectively (11-13). One of the groups suggested that cytosolic cathepsin L-type protease activity might modulate thyroid hormone receptor activity by regulating the turnover of its heterodimerization partner, $\operatorname{RXR} \alpha(11)$.

Several studies have demonstrated sensitizing effect of retinoids to ionizing radiation (IR) in various tumors (14-17). Radiosensitization is one of the many important cellular responses to RA. The mechanism of radiosensitization by retinoids is not fully understood, although some suggestions have been reported $(18,19)$. Thus, it is of interest to investigate the function of $\mathrm{RXR} \alpha \mathrm{LBD}$ fragment in the radiosensitization by RA in cancer cells. We report that $\mathrm{RXR} \alpha$ LBD fragment completely blocks radiosensitizing action of RA, highlighting the importance of $\operatorname{RAR} \gamma$ in the radiosensitizing process induced by $\mathrm{RA}$ and suggesting the possibility that the presence of $\mathrm{RXR} \alpha \mathrm{LBD}$ fragment may serve as a determinant for the susceptibility to radiosensitization by RA.

\section{Materials and methods}

Cell culture and plasmid constructs. SiHa cells were grown in minimal essential medium, H460, A549 and H1299 were grown in RPMI-1640 medium, supplemented with $10 \%$ fetal bovine serum (FBS). Retroviral vector for RXR $\alpha$ mutant expression was prepared as following. The cDNA covering amino acids $222-462$ of $\mathrm{RXR} \alpha$ was amplified by polymerase 

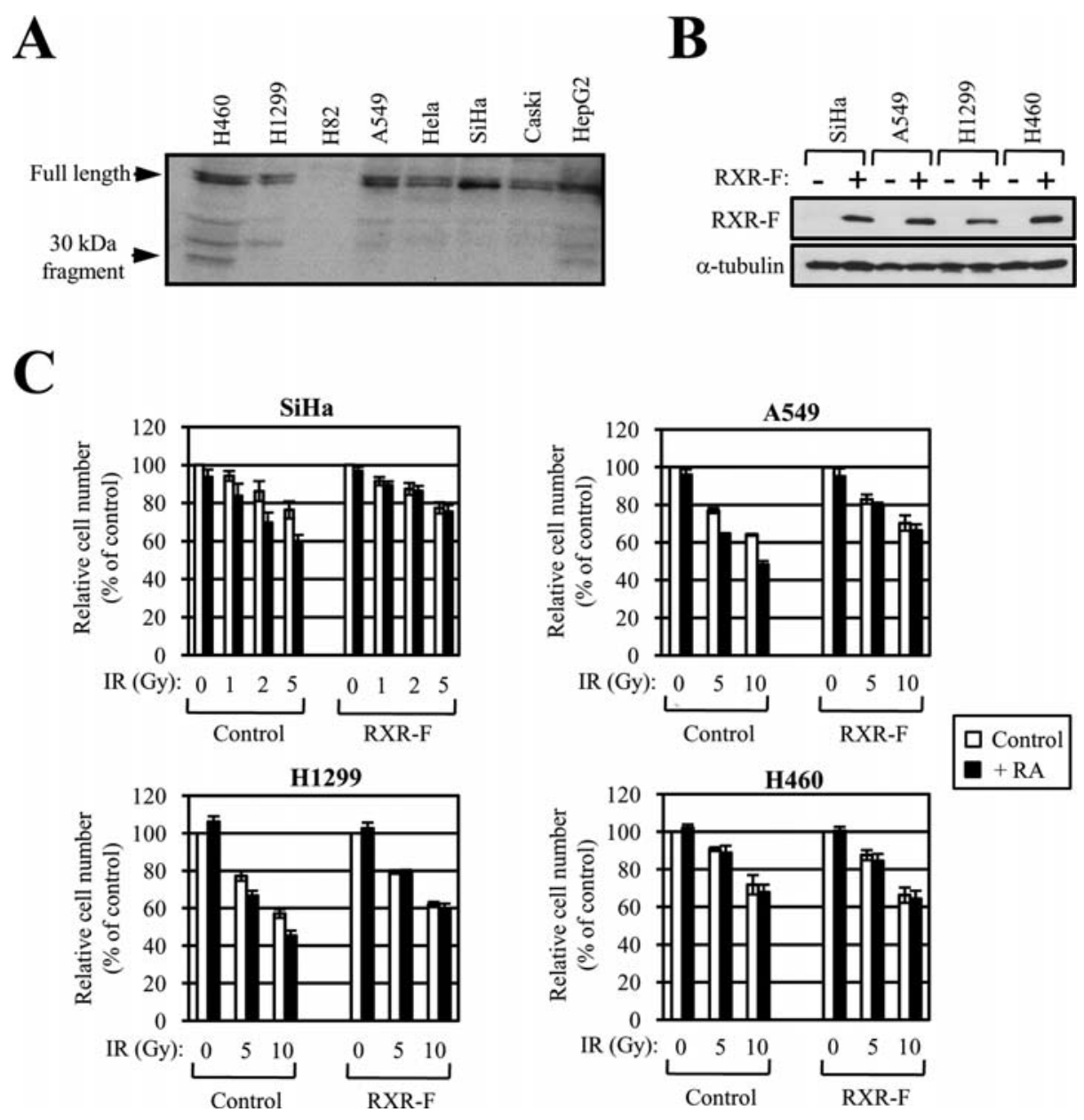

Figure 1. LBD fragment of RXR $\alpha$ blocks the sensitizing effect of RA on IR-induced growth inhibition. (A) Variation in the presence of C-terminal $30 \mathrm{kDa}$ fragment of RXR $\alpha$ among various cancer cell lines. Total cell lysates $(40 \mu \mathrm{g})$ of the indicated cell lines were analyzed by Western blotting using the antibody specific for C-terminal region of RXR $\alpha$ (sc-46659, Santa Cruz Biotechnology). (B) Establishment of stable cell lines expressing the LBD fragment of RXR $\alpha$ (RXR-F). Indicated cells were infected with control retrovirus or retrovirus harboring the cDNA for 222-462 amino acid residues of RXR $\alpha$. Expression of LBD fragment of RXR $\alpha$ was confirmed by Western blotting using $10 \mu \mathrm{g}$ of total cell lysate. (C) The effect of RXR-F overexpression on the growth inhibition by IR and RA. Stable cell lines expressing RXR-F or not were seeded in 96-well plates and treated with RA at $1 \mu \mathrm{M}$ for $12 \mathrm{~h}$ or not. Cells were then irradiated at the indicated dose and allowed to grow for $72 \mathrm{~h}$. The number of viable cells was determined by MTS assay. Experiments were done in triplicates.

chain reaction with an addition of start codon at the $\mathrm{N}$ terminus, and inserted into the cloning site of a retroviral vector MFG-puro in a right orientation.

Establishment of stable cell lines. Retroviruses were prepared by introducing MFG construct into retrovirus packaging cell line, H29D, by transient transfection using lipofectamine 2000 (Invitrogen). After $72 \mathrm{~h}$, the supernatants containing viruses were harvested and filtered through $0.2 \mu \mathrm{M}$ pores after addition of Polybrene $(6 \mu \mathrm{g} / \mathrm{ml})$. Target cell lines were infected with the viruses titered between $10^{5}$ and $5 \times 10^{5} / \mathrm{ml}$ and selected for 3 days in growth medium containing puromycin at $2 \mu \mathrm{g} / \mathrm{ml}$.

Western blotting. Cell lysates were boiled in sodium dodecyl sulfate (SDS) sample buffer, resolved by SDS-polyacrylamide gel electrophoresis ( 8 or $12.5 \%$ polyacrylamide), and transferred to nitrocellulose. After transfer, the membranes were blocked in $5 \%$ milk in TBST $(10 \mathrm{mM}$ Tris- $\mathrm{HCl}, \mathrm{pH} 8.0$, $150 \mathrm{mM} \mathrm{NaCl}$, and $0.05 \%$ Tween-20) for $30 \mathrm{~min}$ and incubated with primary antibody in 5\% milk in TBST for $2 \mathrm{~h}$ at room temperature. The membranes were washed three times with TBST, and incubated for $1 \mathrm{~h}$ at room temperature in TBST containing horseradish peroxidase-linked antimouse or rabbit immunoglobulin (Santa Cruz). After triple washes in TBST, immunoreactive products were detected by chemiluminescence with an enhanced chemiluminescence system (ECL, Amersham).

Growth inhibition. Cells were seeded in 96-well plates and allowed to attach for $24 \mathrm{~h}$, and then treated with all-transretinoic acid (RA) at $1 \mu \mathrm{M}$ for $12 \mathrm{~h}$ or not. Cells were then irradiated or not and allowed to grow for $72 \mathrm{~h}$. The number of viable cells was determined using the 3-(4,5-dimethylthiazol2-yl)-5-(3-carboxymethoxyphenyl)-2-(4-sulfophenyl)-2Htetrazolium inner salt (MTS) reduction assay (Cell Titer 96 AQueous Non-radioactive Cell Proliferation Assay, Promega, Madison, WI) according to the manufacturer's protocol. Three replicates were done for each treatment.

Colony-formation assay. Clonogenic cell survival was evaluated by colony-forming assay. Cells were seeded at a 
A

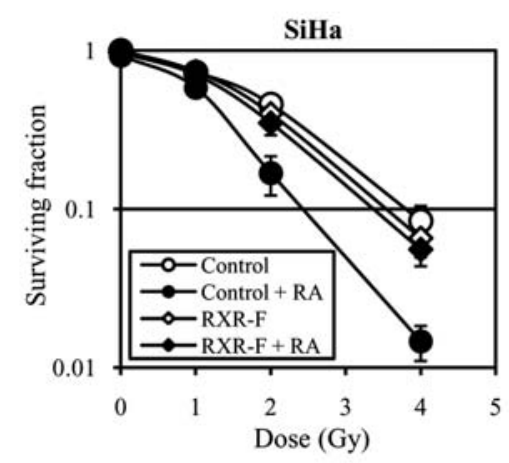

C

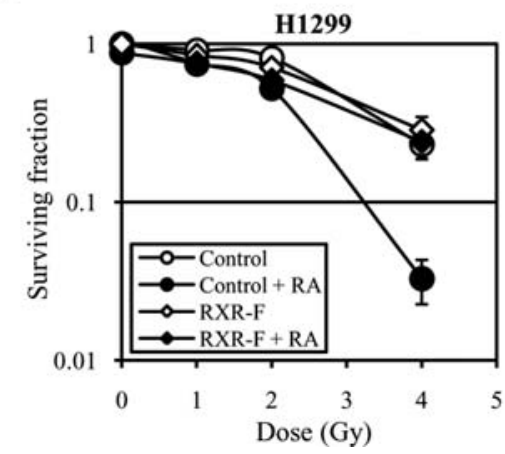

B

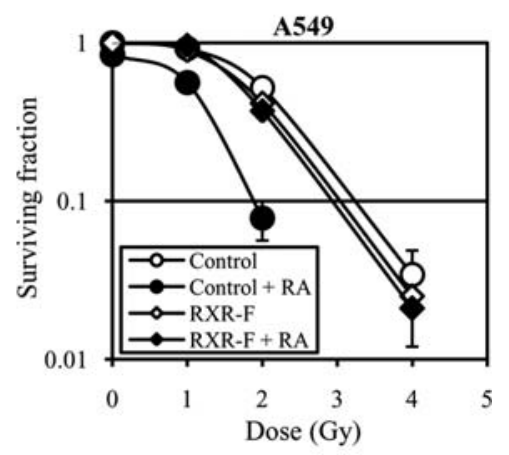

D

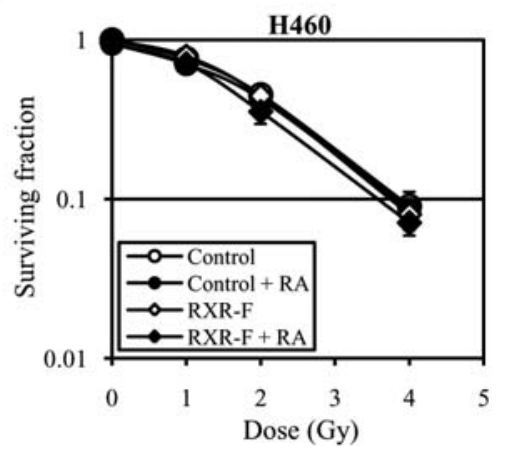

Figure 2. LBD fragment of RXR $\alpha$ blocks radiosensitizing effect of RA in colony formation assay. Indicated stable cell lines were seeded (300 cells in 60-mm dishes) and irradiated at the indicated dose after pretreatment of RA at $1 \mu \mathrm{M}$ for $12 \mathrm{~h}$ or not. After 10-14 days of incubation, the colonies larger than $0.6 \mathrm{~mm}$ in diameter were counted. Experiments were done in triplicates.

density of 200 cells $/ 60 \mathrm{~mm}$ dish a day before the treatment of RA $(1 \mu \mathrm{M})$. Cells were then irradiated at the indicated doses $12 \mathrm{~h}$ after RA treatment. After 2 weeks of incubation, cells were fixed with $3.7 \%$ formaldehyde and stained with crystal violet. Colonies larger than $0.6 \mathrm{~mm}$ in diameter were counted. Three replicates were done for each treatment.

Cell death analysis. Apoptotic cell death was determined by Annexin V-FITC/propidium iodide double staining using Annexin V-FITC Apoptosis Detection Kit I (BD Biosciences) according to the manufacturer's recommendation. The cells were then analyzed using a FACScan flow cytometer (BD Biosciences).

Irradiation of cells. Cells were plated in $3.5-\mathrm{cm}$ dishes and incubated at $37^{\circ} \mathrm{C}$ under humidified $5 \% \mathrm{CO}_{2}-95 \%$ air in culture medium until cells reached $70-80 \%$ confluent. Cells were then exposed to $\gamma$-rays with ${ }^{137} \mathrm{Cs} \gamma$-ray source (Atomic Energy of Canada, Ltd., Canada) with a dose rate of $3.81 \mathrm{~Gy} / \mathrm{min}$.

\section{Results}

Endogenous $30 \mathrm{kDa}$ LBD fragment of RXRa is present in some cell lines. In a previous report, we demonstrated that $\mathrm{C}$ terminal $30 \mathrm{kDa}$ LBD fragment of RXR $\alpha$ plays a unique role in the regulation of subcellular localization and transcriptional activity of RAR $\gamma(10)$. Since there have been several reports describing the generation of truncated RXR $\alpha$
C-terminal fragment by proteolytic cleavage in cancer cells (11-13), we wanted to check whether $\operatorname{RXR} \alpha \mathrm{C}$-terminal fragment of a similar size was endogenously produced in various cancer cell lines. Using the antibody specific to the $\mathrm{C}$-terminal region of $\mathrm{RXR} \alpha$, we could detect $\mathrm{C}$-terminal fragment of $\mathrm{RXR} \alpha$ at about $30 \mathrm{kDa}$ in certain cells such as H460 lung cancer cells, and HepG2 hepatocarcinoma cells, while there was no detectable level of this $\mathrm{RXR} \alpha$ fragment in other cell lines tested (Fig. 1A).

$L B D$ fragment of $R X R a$ blocks the synergistic action of $R A$ on $I R$-induced growth inhibition. To examine the function of $\mathrm{RXR} \alpha \mathrm{LBD}$ fragment, we first tried to establish stable cell lines that express the RXR $\alpha$ LBD fragment (RXR-F) using retroviral expression system and puromycin selection. For this purpose, we constructed retroviral vector designed to express RXR $\alpha$ fragment of 222-462 amino acid residues, which has been shown to specifically inhibit the nuclear translocation and transcriptional activity of RAR $\gamma(10)$. Three cell lines that do not have detectable endogenous $\mathrm{RXR} \alpha \mathrm{LBD}$ fragment (SiHa, A549 and H1299) in addition to one that have endogenous RXR $\alpha$ LBD fragment (H460) were chosen to establish stable cell lines, and they were confirmed to express RXR-F stably (Fig. 1B).

Firstly, we carried out MTS cell proliferation assay using the established stable cell lines to assess the effect of RXR-F expression on the synergistic action of RA on the growth inhibition by IR (Fig. 1C). As expected, IR inhibited cell growth of all four cell lines tested dose-dependently 
A
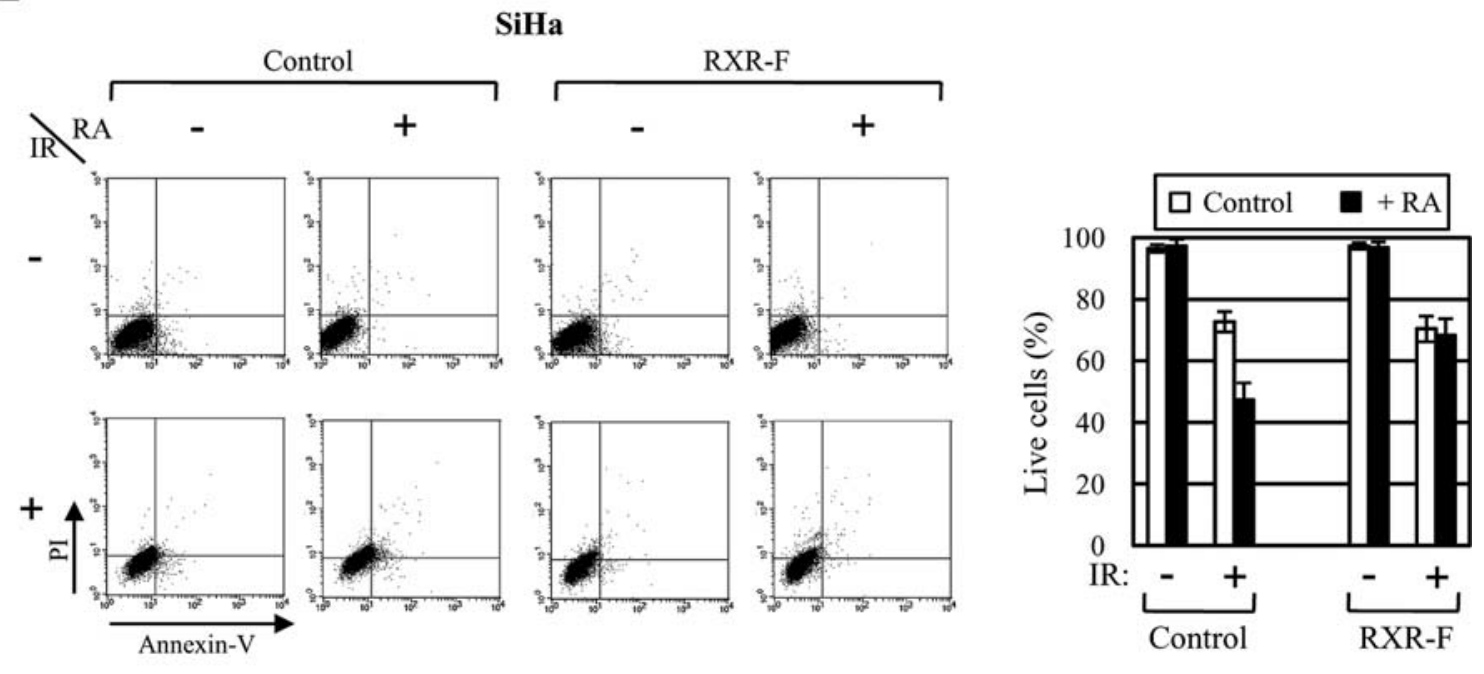

B

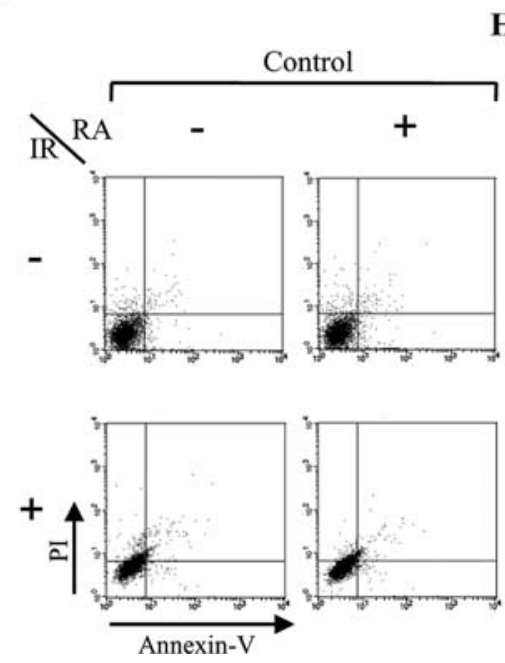

H460
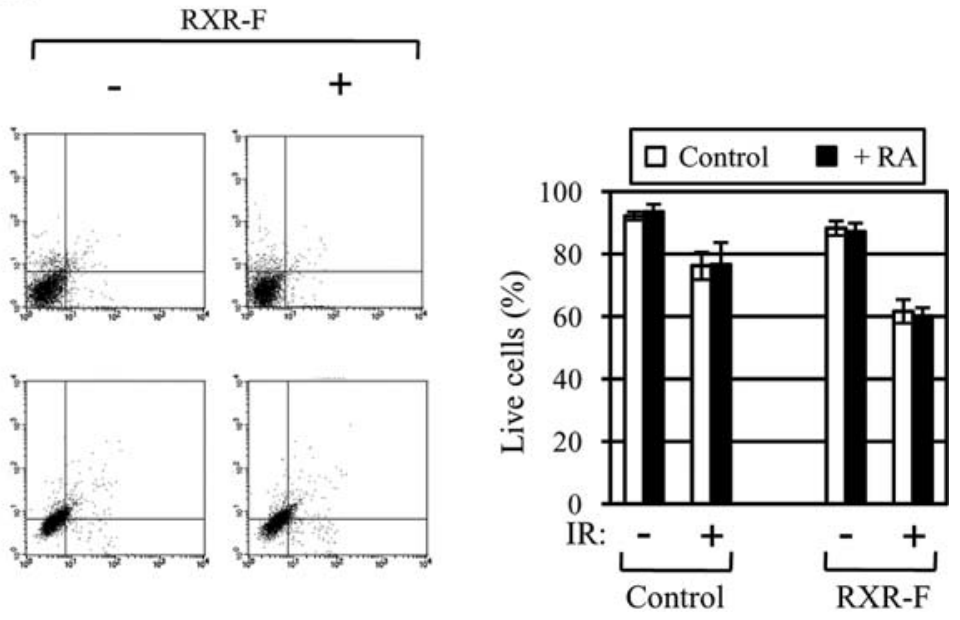

Figure 3. LBD fragment of RXR $\alpha$ blocks radiosensitizing effect of RA in cell death determination assay by FACS analysis. Stable cell lines of SiHa (A) and H460 (B) were irradiated at 5 and $10 \mathrm{~Gy}$, respectively, after pretreatment of RA at $1 \mu \mathrm{M}$ for $12 \mathrm{~h}$. Cell death was determined after $48 \mathrm{~h}$ by Annexin-V/PI staining. The fraction of live cells (lower left section) was plotted. The assays were repeated three times and the representatives results are shown.

regardless of the RXR-F expression. Pretreatment of RA significantly enhanced the growth-inhibitory effect of IR in control cell lines of SiHa, A549 and H1299, which lack endogenous RXR $\alpha$ LBD fragment. When RXR-F was expressed in these cell lines, however, the synergistic effect of RA on the IR-induced growth inhibition was completely blocked. In contrast, RA pretreatment did not cause further growthinhibition after IR treatment in H460 that have endogenous $\mathrm{RXR} \alpha \mathrm{LBD}$ fragment, regardless of ectopic expression of RXR-F.

$L B D$ fragment of $R X R \alpha$ blocks the sensitizing effect of $R A$ on clonogenic survival after IR. We next performed colonyformation assay to evaluate the effect of RXR $\alpha$ LBD fragment on RA-mediated sensitization in clonogenic survival after IR (Fig. 2). Control or RXR-F expressing stable cells were irradiated with or without the pretreatment of RA. The number of colonies formed after a period of incubation decreased as IR dose was increased. The number of surviving colony was decreased more when RA was pretreated before irradiation in SiHa, A549 and H1299 cells. Ectopic expression of RXR-F largely abolished this sensitizing effect of RA (Fig. 2A-C). However, RA pretreatment did not result in sensitization of $\mathrm{H} 460$ cells to IR, regardless of ectopic expression of RXR-F (Fig. 2D). These observations are very similar to the case of growth inhibition assay in Fig. 1C.

LBD fragment of RXRa blocks enhancement of IR-induced cell death by $R A$. We recognized from the above growth inhibition and colony formation assay that RA could sensitize cells without endogenous RXR $\alpha$ LBD fragment to IR, and ectopic RXR-F could block the RA effect. To further support these observations, we chose H460 and SiHa as representative of the with or without endogenous RXR $\alpha$ LBD fragment, respectively, to analyze RA effect on IR-induced cell death. Cells were stained with Annexin-V/PI and analyzed using FACS after combined treatment of RA and IR in the presence or absence of ectopic RXR-F 
A

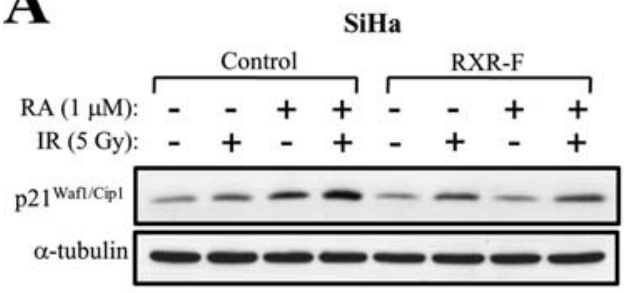

B

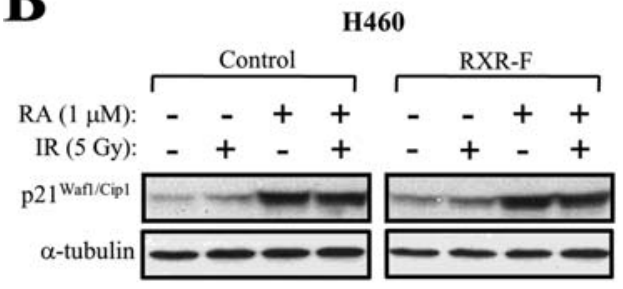

C

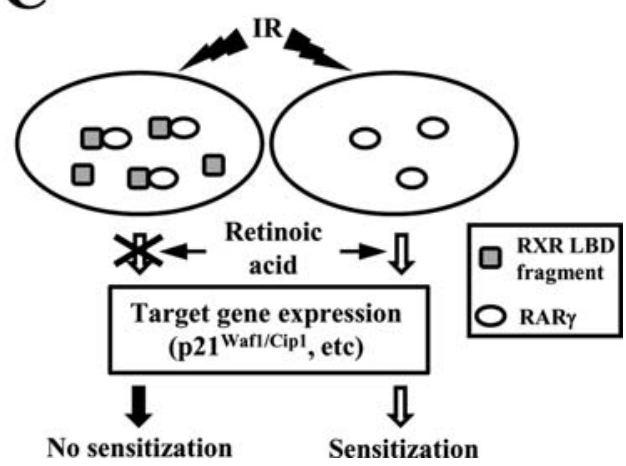

Figure 4. The presence of $\operatorname{RXR} \alpha$ LBD fragment determines radiosensitizing effect of RA. (A) RXR-F expression blocks the RA-mediated induction of $\mathrm{p} 21^{\mathrm{Waf} 1 / \mathrm{Cip} 1}$ and synergistic induction of $\mathrm{p} 21^{\mathrm{Waf} 1 / \mathrm{Cip} 1}$ in combination with IR in SiHa cells. SiHa cells either expressing RXR-F or not were treated with RA at $1 \mu \mathrm{M}$ for $12 \mathrm{~h}$ and irradiated at $5 \mathrm{~Gy}$. Cell lysates were prepared $12 \mathrm{~h}$ after irradiation. Total cell lysates $(30 \mu \mathrm{g})$ were used for Western blot analysis. $\alpha$-tubulin was used as a loading control. (B) p21 Waf1/Cip1 is not induced by RA treatment in H460. The experiment was carried out as in (A). (C) Illustration of the role of $\operatorname{RXR} \alpha \mathrm{LBD}$ fragment as a determinant in radiosensitizing action of $\mathrm{RA}$.

expression. As shown in Fig. 3A, pretreatment of RA caused significant reduction of the percentage of live cells after irradiation in SiHa cell in the absence of RXR-F expression. RXR-F expression blocked again this sensitizing effect of RA. On the other hand, RA pretreatment did not cause increase of cell death after irradiation in H460 (Fig. 3B). Ectopic expression of RXR-F in H460 did not make any difference to the RA effect on IR-induced cell death, but rendered the cells more sensitive to some extent to IR regardless of RA pretreatment.

LBD fragment of $R X R \alpha$ inhibits $p 21^{\text {Wafl/Cipl }}$ induction by $R A$. We next wanted to examine whether $\mathrm{RXR} \alpha \mathrm{LBD}$ fragment can modulate the molecular response of cells to IR in combination with RA. Since cyclin-dependent kinase inhibitor, $\mathrm{p} 21^{\text {Waf1/Cip1 }}$, a well known effector protein for DNA damage response, is known to be induced by both IR and RA (20-22), we decided to determine the expression level of $\mathrm{p} 21^{\mathrm{Waf} 1 / \mathrm{Cip} 1}$ after single or combined treatment of IR and RA. In SiHa control cells, treatment of RA or IR increased the expression of $\mathrm{p} 21^{\mathrm{Waf} 1 / \mathrm{Cip} 1}$, and combined treatment of both resulted in the further synergistic increase of $\mathrm{p} 21^{\text {Waf } 1 / \text { Cip } 1}$ (Fig. 4A). However, RA treatment did not increase p21 Waf1/Cip1 expression regardless of co-treatment of IR in $\mathrm{SiHa}$ cell expressing RXR-F, while $\mathrm{p} 21^{\text {Waf1/Cip } 1}$ induction by IR was intact in these cells. This suggests that RXR-F expression abrogated specifically RA-mediated induction of $\mathrm{p} 21^{\text {Waf1/Cip } 1}$ through specific inhibition of RAR $\gamma$ activity, while leaving the machinery for $\mathrm{p} 21^{\text {Waf } 1 / \text { Cip } 1}$ induction by other kinds of stimuli intact. In H460 cells, on the other hand, RA treatment did not cause significant change in $\mathrm{p} 21^{\text {Waf1/Cip } 1}$ expression from basal or IR-induced level no matter whether RXR-F was ectopically expressed or not (Fig. 4B). IR alone was still able to induce $\mathrm{p} 21^{\text {Waf } 1 / \mathrm{Cip} 1}$ significantly in this cell type, regardless of ectopic expression of RXR-F. It is therefore possible that the endogenous $30 \mathrm{kDa} \mathrm{C}$-terminal fragment of $\mathrm{RXR} \alpha$ may contribute, to some extent, to the lack of p21 Waf1/Cipl induction by RA in $\mathrm{H} 460$.

\section{Discussion}

Based on the previous findings that $\mathrm{RXR} \alpha \mathrm{LBD}$ fragment specifically inhibits $\operatorname{RAR} \gamma$ activity and LBD fragment of $\mathrm{RXR} \alpha$ is produced in cells by proteolytic cleavage, we aimed to evaluate the functional role of $\mathrm{RXR} \alpha \mathrm{LBD}$ fragment in radiosensitization by $\mathrm{RA}$. In the cells without endogenous $\mathrm{RXR} \alpha \mathrm{LBD}$ fragment used in this study, RA worked very well to enhance the response to IR at both cellular and molecular level, and ectopic expression of RXR $\alpha$ LBD fragment in these cells blocked the sensitizing effect of RA. Interestingly, $\mathrm{H} 460$ cells, in which endogenous $\mathrm{RXR} \alpha \mathrm{LBD}$ fragment was detected, did not respond to RA in terms of enhancing IR-induced cellular and molecular response.

Since $\mathrm{p} 21^{\mathrm{Waf} 1 / \mathrm{Cip} 1}$ is known to be induced by both IR and RA (20-22), we chose $\mathrm{p} 21^{\text {Waf } 1 / \text { Cip } 1}$ as an example among known RA-responsive genes to verify the effect of $\operatorname{RXR} \alpha$ LBD fragment on the synergistic induction of downstream target gene by RA in combination with IR. Blocking of RAmediated induction of $\mathrm{p} 21^{\text {Waf1/Cip } 1}$ by ectopic expression of $\mathrm{RXR} \alpha \mathrm{LBD}$ fragment clearly confirms that the actions of the RXR $\alpha$ LBD fragment on RAR $\gamma$ at multiple levels demonstrated in previous study (10) actually operate in concert to repress the induction of endogenous target genes. It has been generally accepted that anti-cancer effects of retinoids are mediated by RARß, and the sensitivity to retinoid is directly correlated to the induction of RARß (23-25). As to radiosensitization, however, the contribution of RARB is controversial $(18,26)$. On the other hand, our results, which demonstrated the decisive role of $\mathrm{RXR} \alpha \mathrm{LBD}$ fragment in preventing the effect of RA enhancing IR-induced responses at both cellular and molecular level, propose RAR $\gamma$ as a main player in radiosensitization by $\mathrm{RA}$, since $\mathrm{RXR} \alpha \mathrm{LBD}$ fragment has been clearly shown to inhibit specifically RAR $\gamma(10)$.

There have been reports that C-terminal fragment of $\mathrm{RXR} \alpha$ similar in size to LBD fragment is produced by proteolytic cleavage (11-13). However, the biological significance of the fragmentation of RXR $\alpha$ was not fully addressed. 
One suggestion was that cathepsin L-type protease might regulate the response to thyroid hormone by modulating thyroid hormone receptor activity through the regulation of the turnover of its heterodimerization partner, $\mathrm{RXR} \alpha$ (11). The work was focused on the regulation of $\operatorname{RXR} \alpha$ protein level by proteolytic cleavage, but not on $\operatorname{RXR} \alpha$ cleavage product itself, thus presenting neither evidence nor insight into the possible functions of the $\mathrm{RXR} \alpha$ cleavage product. Our results demonstrating the active role of RXR $\alpha$ LBD fragment in the regulation of RA-mediated radiosensitization provide new insight into the biological significance of proteolytic cleavage of RXR $\alpha$. Thus, proteolytic cleavage of RXR $\alpha$ can be regarded as the cellular process not only to regulate $\mathrm{RXR} \alpha$ protein level, but also to generate the active specific negative regulator of the biological processes in which RAR $\gamma$ is involved. Since increasing evidence reveals that $R A R \gamma$ is a critical regulator in more biological processes than expected, further study aimed to exploit the property of $\mathrm{RXR} \alpha \mathrm{LBD}$ fragment could provide the means to control various biological processes.

More systematic analysis using larger pool of cell lines or patient specimen might be required to derive a firm conclusion as to the direct correlation between the presence of endogenous RXR $\alpha$ LBD fragment and the loss of radiosensitization by RA. Nevertheless, our results suggest the possibility that the presence of $\mathrm{RXR} \alpha \mathrm{LBD}$ fragment may serve as a determinant for the susceptibility of cancer cells to radiosensitization by RA (Fig. 4C), which can be exploited to develop a prognostic system for the combination radiotherapy with $\mathrm{RA}$.

\section{Acknowledgements}

This study was supported by a grant from Nuclear Research \& Development Program funded by the Korean Ministry of Education, Science and Technology.

\section{References}

1. Chambon P: A decade of molecular biology of retinoic acid receptors. FASEB J 10: 940-954, 1996.

2 Mangelsdorf DJ and Evans RM: The RXR heterodimers and orphan receptors. Cell 83: 841-850, 1995.

3. Kastner P, Mark M and Chambon P: Non-steroid nuclear receptors: what are genetic studies telling us about their role in real life? Cell 83: 859-869, 1995.

4. Taneja R, Bouillet P, Boylan JF, et al: Reexpression of retinoic acid receptor (RAR) gamma or overexpression of RAR alpha or RAR beta in RAR gamma-null F9 cells reveals a partial functional redundancy between the three RAR types. Proc Natl Acad Sci USA 92: 7854-7858, 1995.

5. Marinelli A, Bossi D, Pelicci PG and Minucci S: A redundant oncogenic potential of the retinoic receptor (RAR) alpha, beta and gamma isoforms in acute promyelocytic leukemia. Leukemia 21: 647-650, 2007

6. Mark M, Ghyselinck NB and Chambon P: Function of retinoid nuclear receptors: lessons from genetic and pharmacological dissections of the retinoic acid signaling pathway during mouse embryogenesis. Annu Rev Pharmacol Toxicol 46: 451-480, 2006.
7. Goyette P, Feng Chen C, Wang W, Seguin F and Lohnes D: Characterization of retinoic acid receptor-deficient keratinocytes. J Biol Chem 275: 16497-16505, 2000.

8. Chen CF, Goyette P and Lohnes D: RARgamma acts as a tumor suppressor in mouse keratinocytes. Oncogene 23: 5350-5359, 2004.

9. Purton LE, Dworkin S, Olsen GH, et al: RARgamma is critical for maintaining a balance between hematopoietic stem cell self-renewal and differentiation. J Exp Med 203: 1283-1293, 2006.

10. Han YH, Zhou H, Kim JH, et al: A unique cytoplasmic localization of retinoic acid receptor-gamma and its regulations. J Biol Chem 284: 18503-18514, 2009.

11. Nagaya T, Murata Y, Yamaguchi S, et al: Intracellular proteolytic cleavage of 9-cis-retinoic acid receptor alpha by cathepsin L-type protease is a potential mechanism for modulating thyroid hormone action. J Biol Chem 273: 33166-33173, 1998.

12. Nomura Y, Nagaya T, Yamaguchi S, Katunuma N and Seo H: Cleavage of RXRalpha by a lysosomal enzyme, cathepsin Ltype protease. Biochem Biophys Res Commun 254: 388-394, 1999.

13. Matsushima-Nishiwaki R, Shidoji Y, Nishiwaki S, Moriwaki H and Muto Y: Limited degradation of retinoid X receptor by calpain. Biochem Biophys Res Commun 225: 946-951, 1996.

14. Duchesne GM and Hutchinson LK: Reversible changes in radiation response induced by all-trans retinoic acid. Int J Radiat Oncol Biol Phys 33: 875-880, 1995.

15. Schiller U, Hoffmann W, Bamberg M and Rodemann HP: Alltrans-retinoic acid modulates the radiosensitivity of proliferating cells. Int J Cancer 70: 488-490, 1997.

16. Benbrook DM, Shen-Gunther J, Nunez ER and Dynlacht JR: Differential retinoic acid radiosensitization of cervical carcinoma cell lines. Clin Cancer Res 3: 939-945, 1997.

17. Salsman S, Lu S and Benbrook DM: The mechanism of retinoic acid radiosensitization is independent of AP-1 repression in a cervical carcinoma cell line. Gynecol Oncol 73: 253-256, 1996.

18. Ryu S, Stein JP, Chung CT, Lee YJ and Kim JH: Enhanced apoptosis and radiosensitization by combined 13-cis-retinoic acid and interferon-alpha2a; role of RAR-beta gene. Int J Radiat Oncol Biol Phys 51: 785-790, 2001.

19. Tillmanns TD, Kamelle SA, Guruswamy S, Gould NS Rutledge TL and Benbrook DM: Sensitization of cervical cancer cell lines to low-dose radiation by retinoic acid does not require functional p53. Gynecol Oncol 97: 142-150, 2005.

20. Waldman T, Kinzler KW and Vogelstein B: p21 is necessary for the p53-mediated G1 arrest in human cancer cells. Cancer Res 55: 5187-5190, 1995.

21. Arany I, Whitehead WE, Ember IA and Tyring SK: Dosedependent activation of p21WAF1 transcription by all-transacid in cervical squamous carcinoma cells. Anticancer Res 23: 495-497, 2003.

22. Tanaka T, Suh KS, Lo AM and De Luca LM: p21WAF1/CIP1 is a common transcriptional target of retinoid receptors: pleiotropic regulatory mechanism through RAR/RXR heterodimer and RXR/ RXR homodimer. J Biol Chem 282: 29987-29997, 2007.

23. Hayashi K, Yokozaki H, Naka K, Yasui W, Lotan R and Tahara E: Overexpression of retinoic acid receptor beta induces growth arrest and apoptosis in oral cancer cell lines. Jpn J Cancer Res 92: 42-50, 2001.

24. Hayashi K, Yokozaki H, Goodison S, et al: Inactivation of retinoic acid receptor beta by promoter $\mathrm{CpG}$ hypermethylation in gastric cancer. Differentiation 68: 13-21, 2001.

25. Li M, Song S, Lippman SM, Zhang XK, et al: Induction of retinoic acid receptor-beta suppresses cyclooxygenase- 2 expression in esophageal cancer cells. Oncogene 21: 411-418, 2002.

26. Blaese MA, Santo-Hoeltje L and Rodemann HP: Sensitivity of human tumor cells to retinoids or combined treatment with retinoids and ionizing radiation is not dependent on RAR-beta 2 induction. Strahlenther Onkol 179: 401-409, 2003. 